Article

\title{
Does Property Rights Integrity Improve Tenure Security? Evidence from China's Forest Reform
}

\author{
Yuepeng Zhou ${ }^{1}$ (D), Xianlei Ma ${ }^{1}$, Dengyan $\mathrm{Ji}^{2}{ }^{2}$, Nico Heerink ${ }^{1,3}$, Xiaoping Shi ${ }^{1, *}$ \\ and Hongbin Liu ${ }^{4}$ \\ 1 China Centre for Land Policy Research \& College of Public Administration, Nanjing Agricultural University, \\ Nanjing 210095, China; zhouyuepeng@njau.edu.cn (Y.Z.); maxianlei@njau.edu.cn (X.M.); \\ Nico.Heerink@wur.nl (N.H.) \\ 2 School of Geography and Environmental Engineering, Gannan Normal University, Ganzhou 341000, China; \\ jidengyan288@163.com \\ 3 Development Economics Group, Department of Social Sciences, Wageningen University, \\ 6708 Wageningen, The Netherlands \\ 4 College of Land and Environment, Shenyang Agricultural University, Shenyang 110866, China; \\ liuhongbinsy@163.com \\ * Correspondence: Serena2@njau.edu.cn; Tel.: +86-25-8439-5078
}

Received: 7 May 2018; Accepted: 9 June 2018; Published: 11 June 2018

\begin{abstract}
The purpose of this paper is to examine the impact of land property rights integrity, subdivided into use rights, mortgage rights, and transfer rights, on household perceptions of long-term tenure security in China. To this end, we establish a theoretical framework that links China's collective forest tenure reforms undertaken since 2003 to property rights integrity and two sources of tenure (in)security based on property rights theory: forestland reallocation and expropriation. Probit models are applied in the empirical analysis to household data collected in Jiangxi province in 2011 and 2013. The results indicate that household perceptions of tenure insecurity resulting from forestland reallocation expectations are affected by transfer rights, whereas household perceptions of insecurity resulting from forestland expropriation expectations are not affected by forestland rights. We thus suggest that it is crucial for policymakers to identify the sources of local property rights insecurity before they take steps to strengthen land tenure security. This paper contributes to the available literature on the relationship between property rights integrity and tenure security by identifying different sources of tenure insecurity, emphasizing the effect of property rights integrity on long-term tenure security, and taking into account the potential endogeneity problem.
\end{abstract}

Keywords: forest tenure reform; property rights integrity; tenure security; land reallocation; land expropriation

\section{Introduction}

Forests have increasingly been recognized as a critical element in economic development and ecological balances [1]. In the study of farmland tenure security, an abundance of literature has identified three effects that land tenure security may have on economic outcomes, i.e., investment effect, market effect, and credit effect [2-4]. The decentralization of forest management in some developing countries, for example, Vietnam, Ecuador, and China, has allowed similar research to be extended to the area of forest tenure. A number of studies have provided empirical evidence that forest tenure security stimulates household incentives to invest in forestland [5-9], transfers of forestland to more efficient uses through land markets [10,11], and rural household incomes [12-14]. Regarding the ecosystem, forest tenure security has been found to increase forestation $[15,16]$. 
Despite the importance of forest tenure security for both economic development and the environment, forest tenure is often insecure and/or ill-defined. This applies not only to China [17], but also to many of the world's most biodiverse and forested regions [16]. Before the Rural Land Contracting Law, which was issued in 2003 and prohibited land reallocations, village leaders in rural China periodically reallocated collective (arable and forest) land among rural households within the same village to maintain an egalitarian distribution, eliminate growing inefficiency, and fulfill output quotas [18]. Besides, due to rapid urbanization, large pieces of forestland have been confiscated and converted into non-agricultural land in order to serve public and economic interests. Especially in the southern forestry regions where farmland is limited, forestland is the main type of expropriated land [19]. As a result, ill-defined property rights, forestland reallocations, and forestland expropriations have become major causes of tenure insecurity in China. In order to promote forestry development and achieve sustainable utilization of forest resources, a new round of collective forest tenure reform has been implemented since 2003 in China. One of its main purposes is to clarify the bundle of property rights to forestland contracted by rural households.

Land tenure security depends on many factors, including land tenure system, land characteristics, household characteristics, past and present land policies, cultural norms, and historical context [17]. Little research has been carried out on the potential contribution of property rights on tenure security in forestland. Exceptions are studies done by Holden et al. [17] and Yi et al. [7], which explored factors influencing tenure security through the bundle of rights approach. In this approach, a property rights index is used to represent the strength of the bundle of rights at the household level. Based on data from three provinces in 1980-2005, Holden et al. [17] concluded that local transfer rights enhance tenure security in China. Yi et al. [7] found that disaggregated rights, including the right to convert forestland to cropland, the right to select tree species, the right to use non-timber products, the right to abandon forestland, the right to transfer plots to other villagers, and the right to mortgage forestland, have significantly strengthened owners' perceptions of tenure security and increased forestry investment.

Although the available studies provide some interesting insights into the impact of forest property rights on tenure security perceptions, there are several aspects that need more attention. First of all, these studies mainly examine households' overall perceptions of land loss by asking whether the household expects to own the plot after five years. They do not distinguish between the risk of land loss arising from land reallocation for village self-governance purposes and the risk of land expropriation for the state's public interests. Due to the strict protection policy of arable land and public interest forest in China, forestland expropriation is rising each year. Converted forestland has become a major source of construction land. For example, the area of forest being expropriated has risen from 19,073 ha in 2011 to 22,939 ha in 2012 [20,21]. Land reallocations induced by village self-governance mechanisms differ fundamentally from land expropriations through state interventions. Forest rights may therefore have different effects on these two sources of forest tenure insecurity. Secondly, the focus of the existing literature is mainly on the effect of forestland rights on short-term tenure security perceptions of farmers (for the coming five years). Since forest contract duration can be up to 70 years, medium to long-term property right security perceptions (e.g., the risk of either land reallocation or land expropriation over a longer period) may be more relevant for forest operation and management decisions. Thirdly, the available literature does not take into account the potential endogeneity caused by unobservable variables (e.g., households' risk preferences) that may affect households' awareness of their forestland rights as well as their perceptions of tenure security.

The objective of this paper is to examine the impact of forestland property rights on household perceptions of long-term forest tenure security in China. To achieve this, we distinguish between tenure (in)security related to the risk of forestland reallocation by village leaders, and tenure (in)security related to the risk of forestland expropriation either by the state or by local governments. Different tenure arrangements allocate different combinations of rights to a bundle [22]. We interpret forestland rights as a bundle of rights, that includes use rights, mortgage rights, and transfer rights, 
representing the integrity of forestland property rights. In the empirical analysis, probit models are applied to household data collected in Suichuan county and Fengcheng city (at the county level), Jiangxi province in 2011 and 2013. The selected regions are two of the pilot areas where the new round of forest tenure reform has been implemented since 2004. The reforms in Fengcheng and Suichuan focus on the decentralization of property rights to individual households and restrictions on forestland expropriation. These make the two regions suitable cases to examine the effects of property rights integrity on perceived household tenure security. Our main finding is that a household's forestland reallocation expectation is affected by transfer rights, while a household's perception of forestland expropriation is independent of forestland rights.

The outline of the paper is as follows. Section 2 provides a theoretical framework linking forest tenure reforms, affecting the bundle of forestland property rights, to households' perceived tenure security. Section 3 briefly reviews the collective forest tenure reforms and their impacts on farmers' forestland rights in China. Section 4 presents the materials and methods, including the research area, data collection process, model specification, and estimation strategy. Section 5 reports and interprets the estimation results and discusses the links between property rights, tenure security, and sustainable forest management. Section 6 presents concluding remarks.

\section{Property Rights Integrity and Tenure Security: A Theoretical Framework}

\subsection{Forest Property Rights Integrity}

Multiple rights to land can be held by either individuals or groups, as part of "a bundle of rights". Different rights, such as the right to use or the right to transfer, can be pictured as "sticks in the bundle" [23]. The integrity of property rights refers to the wholeness or completeness of the bundle, i.e., the number of "sticks" in the bundle that a household holds and the extent to which these sticks can be held by households. Specifically, Holden et al. [17] distinguished seven disaggregate rights in a property rights bundle: the right to convert forestland to cropland, the right to change forest type, the right to decide tree species, the right to intercrop trees and agricultural crops, the right to abandon forest, the right to transfer the plot to other villagers, and the right to transfer the plot to outsiders. Yi et al. [7] added mortgage rights with and without certificates to the bundle. We distinguish similar rights in our work, and further take the "right to harvest timber" into consideration. We categorize the bundle into three groups, with a total of 9 specific rights ("sticks"):

(1) Use rights-the rights to convert forestland into farmland, change forest type, decide tree species, plant non-wood forest products, abandon forestland, and the right to harvest timber;

(2) Mortgage rights - the right to use forestland as collateral to obtain credit from formal and informal lenders; and

(3) Transfer rights—-the right to transfer the plot to other villagers, and the right to transfer the plot to outsiders.

The bundle of rights concept can be used to represent the integrity of land property rights and is considered a suitable approach for analyzing how forestland property rights can be enhanced [24].

\subsection{Forest Tenure Security}

Some scholars argue that the completeness, duration, and certainty of each right are major elements of land tenure security [25,26]. Sjaastad and Bromley [27] and Arnot [28], on the other hand, argue that completeness and duration can only be viewed as the contents or composition of property rights, rather than tenure security. They claim that land tenure security merely refers to the assurance (certainty) of rights. Recent studies categorize tenure security into (1) legal tenure security (security inherent to the legal status of property rights and protection from national policies); (2) actual tenure security (security implied by the actual control of property rights); and (3) perceived tenure security (households' perceptions of tenure security) $[29,30]$. 
In this study, we define tenure security as the certainty that a household's rights to land will be recognized by others and protected upon being challenged. Tenure security cannot be measured directly. To a large extent, it is what people perceive it to be [23]. Holden et al. [31] pointed out that land expropriation (by the state) and land reallocation (by the village committee) are the two main sources of land tenure insecurity in China. The state holds the right to expropriate land for the purposes of infrastructure construction, urban expansion, and conservation of natural resources, while the village committee has the right to reallocate land in response to demographic changes. Households' perceptions of tenure insecurity may further be affected by ambiguity, overlap, or conflict in existing laws; the unreliable enforcement of laws, negligence or corruption; the violation of the law by government officials; and other forces $[29,30]$.

\subsection{The Impact of Property Rights Integrity on Tenure Security}

Figure 1 provides a framework that links China's collective forest tenure reforms undertaken since 2003 to property rights and perceived tenure security. As shown in that figure, the collective forest reforms have provided farmers with a bundle of land property rights (including use rights, transfer rights, and mortgage rights, see Step 1 in Figure 1). Existing studies of the relationship between the new round of collective forest tenure reform and forestland tenure security mainly focus on the direct impact on farmers' perceived forestland tenure security (Step 2) [7,17]. However, these studies do not distinguish between different threats of tenure security, i.e., the underlying mechanisms (Step 3). The enforcement of formal laws and regulations depends on (1) public governance by the state at different levels in the case of land expropriation for the public benefit; and (2) village self-governance, an informal institution at the local level, in the case of land reallocation.

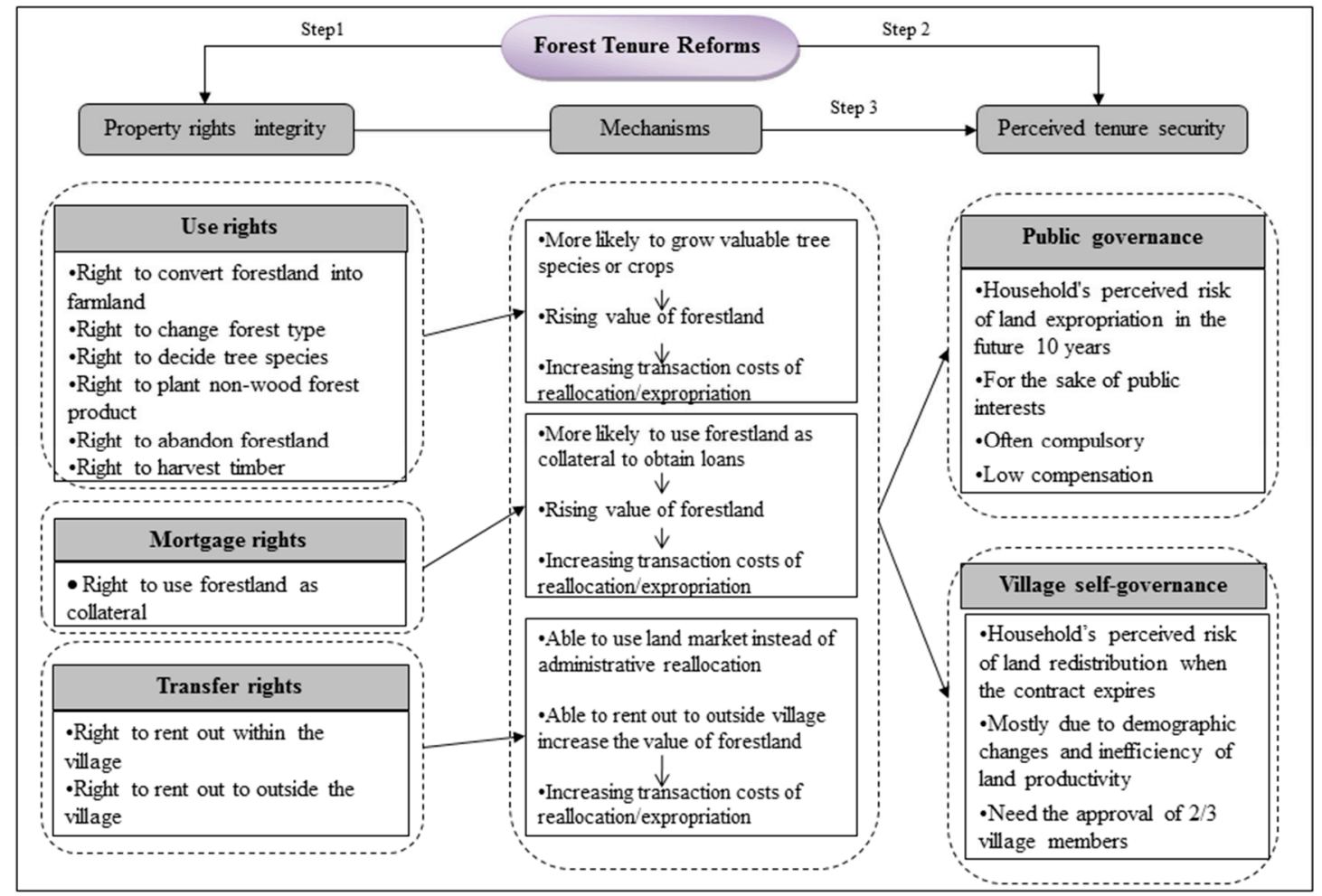

Figure 1. Links between forest property rights integrity and tenure security.

From an aggregate perspective, the possession of land rights is expected to increase farmers' perceived tenure security in two ways: first, a wider scope and higher integrity of forestland rights owned by households provide stronger private control of forestland, and thus weaker control and 
regulation by the central government, local government, and village committee; the more complete the land rights received, the more secure farmers will perceive the land to be. Second, more complete forestland rights may induce more investments by rural households in their forestland, and thereby increase its value. As a result, these households will have more bargaining power, which will increase the transaction costs of land expropriation and reallocation and consequently reduce the risk of losing forestland $[32,33]$.

From a disaggregate perspective, use rights, mortgage rights, and transfer rights may impose different effects on tenure security. Households who possess more complete use rights are expected to plant more valuable tree species that generate more revenue each year. The increase of forestland values would increase the land reallocation and expropriation transaction costs made by village leaders and local governments. Therefore, household expectations regarding the likelihood of forestland reallocations and expropriations will be reduced. Similarly, forestland that can be used as collateral becomes more valuable property, which is expected to have similar effects on the transaction costs of land reallocation and expropriation and on tenure security. The development of village-level land rental markets induced by transfer rights assigned to a household can replace administrative land reallocations as a way to reallocate land resources, thereby reducing the likelihood of such reallocations and increasing tenure security [34]. On the other hand, the right to transfer land either within or outside the village is expected to add value to forestland. Thus, the transaction costs of either reallocation or expropriation will be increased, and the risk that a household's property rights will be not recognized will therefore be lowered.

To sum up, property rights integrity may increase tenure security by increasing the value of land, the subsequent increase in transaction costs involved in land reallocation and expropriation, and the enhanced bargaining power of rural households holding the land rights. Bargaining power may differ significantly between land expropriation and reallocation due to different governance mechanisms. China's Constitution, which was revised in 2004, stipulates that the state can expropriate rural land for the public interest against compensation. The Land Management Law, which was revised in 2004, also regulates that the state may either expropriate or requisite land, according to law, for the public interest, and shall compensate accordingly. However, none of the current laws or regulations has defined the exact meaning of "public interest", nor the entity having the right to affirm "public interest". Therefore, "public interest" becomes a highly abstract concept in China (and many other countries). Consequently, in the current context, local governments may expropriate land either without taking the public interest into account or with compensations far below the standard stipulated by law, thereby depriving farmers' rights and interests $[35,36]$. The process of expropriation often involves either threats of violence or actual violence, and attempts by expropriated farmers to protest against perceived injustice can be blocked in various ways [37]. There are no independent courts for the owners of rural farmland to appeal for unjust treatment [38]. Therefore, higher property rights integrity may only provide a weak contribution to perceived tenure security in the face of land expropriation.

The situation is different with village-level land reallocations. Households in villages with a high population density and mobility generally favor frequent land reallocations to keep up with the changes in population and labor composition [39]. Decisions to reallocate land among the households in a village are made at the village representative meeting, and require approval by more than two thirds of the villagers. This enables farmers to be involved in making decisions on whether to reallocate land or not. Hence, farmers usually have more bargaining power in land reallocations than in land expropriation.

On the basis of this framework, this study intends to test two hypotheses:

Proposition 1. More integrated forest property rights increase perceived tenure security by increasing the transaction costs of forestland expropriation and reallocation and the bargaining power of property rights holders. 
Proposition 2. The effects of forest property rights integrity on household perceptions of tenure insecurity related to village-level land reallocations exceed the effects of tenure insecurity perceptions related to government-led land expropriations.

\section{Collective Forest Tenure Reforms in China}

In the late 1970s, China started a drastic arable land reform known as the Household Responsibility System (HRS), which has brought about remarkable success in agricultural productivity [40]. The reform was later extended to the forestry sector. There have been three major forest tenure reforms since the late 1970s: the "Three Fixes" policy during 1979-1991, the forestry market reform during the 1990s, and the new round of forest reform since 2003. These reforms have gradually promoted the development of collective forestry.

In the 1980s, following the success of the HRS, the "Three Fixes" policy was launched to establish a forestry production responsibility system (collective management). Specifically, it aimed to distribute the forestland to individual households, and fix three issues pertaining to forest tenure, i.e., clarifying rights to forests (family plots), delimiting the boundaries of private plots (responsibility hills), and establishing a forestry production responsibility system (collective management) [17,41,42]. By the end of 1986, over $70 \%$ of the collective forestland was successfully transferred to households [43]. Three forms of forest tenure were established: family plots, responsibility plots, and collective management plots [44]. The collective remained the owner of all forest plots. For family plots and responsibility plots, the use rights were allocated to households, while use rights of the collective management plots remained with the collective. Trees planted on family plots were owned by the households, while they continued to be owned by the collective for responsibility plots. Decision making was done by the village leadership for collective plots, while it was shared by the collective and households for responsibility plots [45].

Through the reform, households obtained some use rights for the forestland they contracted. For instance, they were provided with the right to convert forestland into farmland, the right to change forest type, the right to decide tree species, and the right to plant non-wood forest products (see Table 1). However, to protect the forest, some rights were still limited. As shown in Table 1, usufruct rights, such as the harvest rights, and disposal rights, such as transfer rights, shareholder rights, and inheritance rights, were incomplete for family plots. Such property rights were unavailable for responsibility plots, as those remained with the state [17]. As a result, farmers perceived high tenure insecurity under the uncertain policy environment, which included frequent policy changes, the restriction of logging permits, control of the timber market, and high forest taxes and fees. No significant increases occurred in the planting of new trees in response to the "Three Fixes" policy. In some regions, especially in southern China where the forest coverage was high, the distribution of forestland even led to widespread deforestation akin to the "Tragedy of the Commons" in the mid-1980s [17,41,42,46].

Under this circumstance, in 1987, the State Council issued a document titled Instructions on strengthening the forest resource management in the southern collective forest zone and resolutely stopping deforestation, which stipulated that all large-scale collective timber forests should not continue to be divided and allocated to households, and that the use rights should be returned to the collectives. Hence, this document marked the suspension of the "Three Fixes" policy reform.

Following China's pronouncement to establish a market economy in 1992, the central government issued The General Outline of Forestry Economic System Reform in 1995. This granted forestland use rights to individual rural households, forestry cooperative organizations, and other investors. Due to a lack of investment capacity and access to credit, many farmers transferred their contracted forestland to large holders with more capital. However, the concentration of forestland among large holders did not achieve the anticipated benefits of economy of scale. A heavy tax burden imposed on forest operators and difficulties in obtaining harvest permits inhibited them from investing in forestland, and the productivity of collective forests decreased. Although forest operators were granted more 
complete forestry rights during this period, the country faced a dilemma: importing huge quantities of timber while vast tracts of forestland inland laid unused [41].

Table 1. Collective forest tenure reforms and changes in bundles of rights in China.

\begin{tabular}{|c|c|c|}
\hline Stage & Reform Measures & Bundle of Forestland Rights \\
\hline $\begin{array}{l}\text { "Three Fixes" reform } \\
\text { in 1980s }\end{array}$ & $\begin{array}{l}\text { - } \\
\text { - } \quad \text { Delineating private plots and } \\
\text { responsibility plots } \\
\text { Establishing the production } \\
\text { responsibility system }\end{array}$ & $\begin{array}{l}\text { - Partial use rights of family and responsibility hills } \\
\text { Partial usufruct rights of family and responsibility hills } \\
\text { (timber harvesting from the family or responsibility plots } \\
\text { needs the approval of the local government) } \\
\text { - Partial disposal rights of family plots (e.g., incomplete land } \\
\text { transfer rights, shareholder rights, and inherit rights), } \\
\text { but no disposal rights of responsibility plots }\end{array}$ \\
\hline $\begin{array}{l}\text { Forestry market } \\
\text { reform experiment } \\
(1992-1998)\end{array}$ & $\begin{array}{l}\text { Establishing a forest market, } \\
\text { optimizing allocation of forest } \\
\text { resources by providing farmers with } \\
\text { rights to transfer, lease, and mortgage } \\
\text { - } \quad \text { Promoting scaled operation of forest }\end{array}$ & $\begin{array}{l}\text { - The ownership of woods is allowed to be transferred/sold } \\
\text { - The use right of forestland is allowed to be transferred }\end{array}$ \\
\hline $\begin{array}{l}\text { New round of reform } \\
\text { since } 2003\end{array}$ & $\begin{array}{l}\text { - Further clarifying collective forest } \\
\text { property rights via } \\
\text { contract management } \\
\text { - Further stabilizing the contractual } \\
\text { relationship for a collective } \\
\text { contracted forest } \\
\text { - Developing collective } \\
\text { joint-stock business. }\end{array}$ & $\begin{array}{l}\text { - More use rights of family hills and responsibility hills (e.g., } \\
\text { rights to convert forestland to arable land, independently } \\
\text { choose tree species, manage non-timber forest products, } \\
\text { abandon forestland) } \\
\text { - More complete usufruct rights of private and responsibility } \\
\text { plots (reduce wood and bamboo tax and fees, } \\
\text { relax limitations on harvesting timber) } \\
\text { More complete forestland disposal rights (e.g., right to } \\
\text { subcontract, lease, transfer, and mortgage forestland use } \\
\text { rights and tree ownership). }\end{array}$ \\
\hline
\end{tabular}

Source: Sorted by the authors based on central government documents.

Against this background, a new round of forest tenure reform, named Resolutions on Forestry Development, was introduced in 2003 to provide more forest management incentives to farmers. This reform basically followed the direction of the "Three Fixes" forestry reform in the 1980s [44]. The main features of this round of reform were:

(1) Providing farmers with more complete forest rights. For example, they can select tree species, interchange different forest types (among timber forest, economic forest, and fuel wood forest), and so on. Through this measure, farmers, rather than the village committee, became the main decision-makers of collective forestland [7].

(2) Guaranteeing the usufruct benefits of forestry managers by reducing wood and bamboo tax and fees, relaxing the harvesting regulation gradually, and reforming the collection, management, and use of forest cultivation fund.

(3) Granting farmers more rights to dispose of forestland, such as transfer rights and mortgage rights. Due to improvements by local governments in the financial system, farmers can use their land and timber as collateral to obtain loans for forestland investment and management. Local forest transaction centers have also been set up to facilitate the transfer of forestland and the sale of timber [47].

In conclusion, the new round of collective forest tenure reform granted more forest property rights (both forestland rights and forest rights) to households. Table 1 summarizes the collective forest tenure reforms and the changes in the bundle of forestland rights that occurred in China since the 1980s.

\section{Materials and Methods}

\subsection{Research Site and Data Collection}

As one of the provinces with the richest forestry resources in China, Jiangxi had 10.7 million hectares of forests in 2013. The forest cover rate is approximately $60 \%$, which is much higher than the national average of $21.63 \%$, and ranks second in China (after Fujian province) [48]. Following Fujian province, 
Jiangxi province began a new round of forest tenure reform in 2004. After the pilot and promotion stage, the main part of the reform (property rights clarification) was basically completed by 2007.

According to economic development status, geographical location, and forestry development level, Suichuan county and Fengcheng city (a county-level city) were selected as the research area. As shown in Figure 2, Suichuan county is located in the southern part of Jiangxi province, while Fengcheng city lies in the north of Jiangxi province. Suichuan is a relatively poor and underdeveloped county (the GDP per capita was 11,894 RMB in 2011), while Fengcheng is a relatively wealthy and more developed city (the GDP per capita was 21,500 RMB in 2011). Both regions have a long history of forestry development, and forestry production plays an important role in the local rural development and farmers' livelihoods. As two of the pilot areas of the new round of forest tenure reform, the reform in Fengcheng and Suichuan focuses on the restriction of forestland expropriation and promotion of forestland rental market development. These make the two regions appropriate cases to examine the effects of the new round of forest tenure reform.

Data used in our study came from a household-level and village-level survey conducted in 2011. Using a stratified random sampling method, we selected 14 villages from Suichuan county and 15 from Fengcheng city. Around 10 households from each village were randomly selected, according to the village size (the number of households in each village ranged from 90-685 in Fengcheng and 116-1997 in Suichuan), and a total of 289 households were surveyed. The information that was collected includes household-level data on household characteristics, forestland characteristics, forestland property rights, and related information about forestland production, as well as village-level survey data on forestry management and forestland property rights. To meet the purpose of our study, we carried out a supplementary survey in 2013 to collect additional information about forestland property rights.

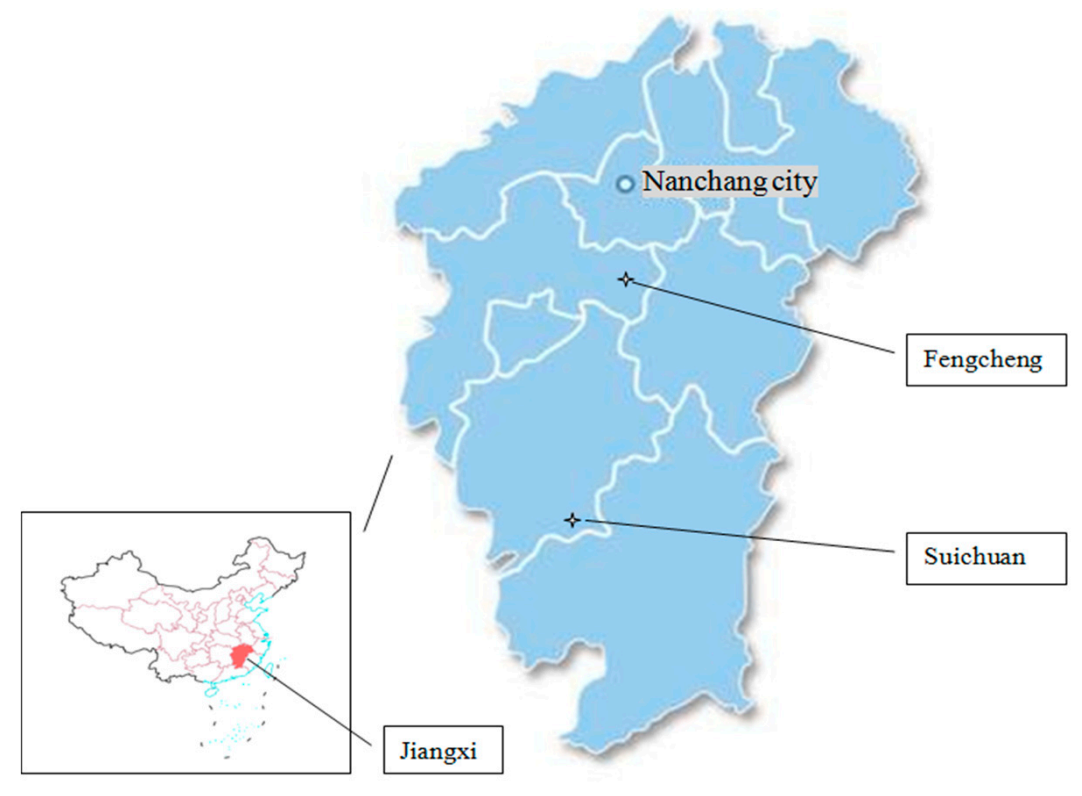

Figure 2. Location of research areas.

\subsection{Definition, Descriptive Statistics, and Expected Effects}

Table 2 shows the definitions and descriptive statistics of the variables used in the analysis. The variables are grouped into perceived forest tenure security variables and property rights integrity, while the control variables are subdivided into actual tenure security variables and characteristics of the household and village. 
Table 2. Definition and descriptive statistics of variables used in the models.

\begin{tabular}{|c|c|c|c|c|c|c|c|}
\hline \multirow{2}{*}{ Variable } & \multirow{2}{*}{ Definition } & \multirow{2}{*}{ Mean } & \multirow{2}{*}{ S.D. } & \multirow{2}{*}{$t$ test $1^{\mathrm{a}}$} & \multirow{2}{*}{$t$ test $2^{\mathrm{b}}$} & \multicolumn{2}{|c|}{ Exp. Sign ${ }^{c}$} \\
\hline & & & & & & $\mathbf{R}$ & $\mathrm{E}$ \\
\hline \multicolumn{8}{|c|}{ Perceived tenure security variables (dependent variables) } \\
\hline Reallocation perception & $\begin{array}{l}\text { Households' perception of the possibility of forestland reallocation after the expiry of } \\
\text { contracts: } 1=\text { will not happen, } 0=\text { otherwise }\end{array}$ & 0.35 & 0.48 & - & - & - & - \\
\hline Expropriation perception & $\begin{array}{l}\text { Households' perception of the possibility of forestland expropriation in the next } 10 \text { years: } \\
1=\text { will not happen, } 0=\text { otherwise }\end{array}$ & 0.40 & 0.49 & - & - & - & - \\
\hline \multicolumn{8}{|l|}{ Property rights integrity $(0-3)$} \\
\hline Use rights & $\begin{array}{l}\text { Average values of the awareness of the right to convert forestland to cropland, the right to } \\
\text { change forest type, the right to independently choose tree species, the right to manage } \\
\text { non-wood forest products, and the right to abandon forestland }\end{array}$ & 2.17 & 0.78 & $-2.24^{* *}$ & -0.34 & + & + \\
\hline Mortgage rights & Awareness of mortgage rights & 1.29 & 1.12 & -0.84 & -0.42 & + & + \\
\hline Transfer rights & Average values of awareness of the right to rent land out to other villagers and outsiders & 2.36 & 0.95 & $-1.32 *$ & $-1.53^{*}$ & $+/-$ & $+/-$ \\
\hline \multicolumn{8}{|l|}{ Actual tenure security variables } \\
\hline Forest certificate & Households possesses a forest certificate: $1=$ yes, $0=$ otherwise & 0.75 & 0.43 & $-3.04 * * *$ & $-2.73^{* * *}$ & + & + \\
\hline Forestland reallocation frequency & Times that forestland reallocations occurred & 0.19 & 0.61 & $2.37^{* * *}$ & 0.44 & - & - \\
\hline \multicolumn{8}{|l|}{ Household characteristics } \\
\hline Age of household head & Age of the household head & 52.67 & 10.46 & 0.51 & $1.88^{* *}$ & $+/-$ & $+/-$ \\
\hline Education of household head & Years of education of the household head (year) & 6.74 & 3.06 & $-1.81 * *$ & $-2.95^{* * *}$ & + & + \\
\hline Share of off-farm laborers & Number of off-farm laborers/household size & 0.10 & 0.19 & $2.03^{* *}$ & -1.15 & - & - \\
\hline Forestland area & Total area of forestland contracted by the household $\left(\mathrm{mu}^{\mathrm{d}}\right)$ & 18.74 & 27.15 & 0.23 & $-1.34 *$ & - & - \\
\hline Number of forestland plots & The initial number of forestland plots & 2.63 & 2.07 & $-1.82 * *$ & $-1.53 *$ & - & - \\
\hline \multicolumn{8}{|l|}{ Village characteristics } \\
\hline Forestland contract period & Period of forestland contract in the village ( $1=30$ years, $2=50$ years, $3=70$ years $)$ & 1.78 & 0.69 & -0.64 & $1.81^{* *}$ & + & + \\
\hline Distance to township & Actual distance from the village to the township $(\mathrm{km})$ & 4.86 & 2.98 & 0.21 & $-2.08 * *$ & + & + \\
\hline Net income per capita & Net income per capita in the village (yuan) & 2447 & 936 & $3.19^{* * *}$ & 1.11 & - & - \\
\hline Years the village cadre have been in office & Years the village cadre have been in office (year) & 10.81 & 9.49 & $1.26^{*}$ & 0.89 & + & I \\
\hline Education of village cadre & Years of education of the village cadre (year) & 9.82 & 2.72 & $-3.82 * * *$ & -0.49 & + & / \\
\hline Regional dummy & $1=$ Fengcheng city, $0=$ Suichuan county & 0.48 & 0.50 & $4.83^{* * *}$ & $2.97 * * *$ & $+/-$ & $+/-$ \\
\hline
\end{tabular}

Notes: ${ }^{a}: t$-test for differences in the mean values of the variable between two reallocation perception groups $\left(1=\right.$ will not happen, $0=$ otherwise). ${ }^{b}: t$-test for differences in the mean values

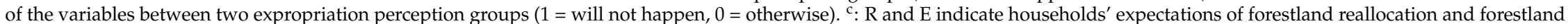

expropriation, respectively. ${ }^{\mathrm{d}}: 1$ hectare $=15 \mathrm{mu} ; 1$ US dollar $=6.19$ yuan in 2013. 


\subsubsection{Perceived Tenure Security}

As mentioned above, we consider two sources of tenure (in)security: (i) the expected possibility of forestland reallocation after the expiry of the current land contracts; and (ii) the expected possibility of forestland expropriation in the next 10 years. The former is associated with local village self-governance, while the latter mostly depends on the public governance of land for public interests.

Each risk expectation takes the value of 0 if farmers think that it is possible that reallocation/expropriation will happen (insecurity), and 1 if they think that it will not happen in the next 10 years (security). As can be seen in Table 1, only 35\% of the sampled households firmly believed that the forestland will not be reallocated, while $40 \%$ expected that it will not be expropriated.

\subsubsection{Bundle of Forestland Rights}

With regard to property rights integrity, each right in the bundle is assigned a value of 0 (if a household considers itself not to hold such a right); 1 (if he/she is not sure of having such a right); 2 (if he/she holds the right upon village committee approval); and 3 (if he/she holds the right, even without village committee approval). To address multicollinearity, the usufruct rights variable is calculated by the mean of the six related rights, and the transfer rights variable is calculated by the mean of the two related rights. In the end, following Holden et al. [17], we considered three categories of rights indexes in the models: (the average of) use rights, mortgage rights, and (the average of) transfer rights.

The mean scores for use rights, mortgage rights, and transfer rights are 2.17, 1.29, and 2.36 (out of 3), respectively, which indicate that the households in our sample perceived more complete transfer rights and use rights than mortgage rights. The scores on use and transfer rights are significantly different between the group of respondents who expected that land reallocation (expropriation) will not happen and the group who expected it to happen (see t-test scores in Table 2).

\subsubsection{Actual Tenure Security}

According to Van Gelder [29] and Ma et al. [30], tenure security can be divided into legal, actual, and perceived security. Legal and actual tenure security are likely to affect perceived security. There is a global trend towards forestland tenure formalization, which is intended to simultaneously strengthen tenure security and reduce deforestation [16]. Legal tenure security, which is represented by the laws and regulations, is the same nationwide in China. Therefore, it cannot explain differences in tenure security perceptions of the respondents to our survey. Possession of a forestland certificate and the number of reallocations that occurred reflect how legal rules are enforced in practice, and are used as indicators of actual tenure security in our study. Formal certificates are intended to provide households with expectations of long-term stability, and thereby will provide households with perceptions of higher security. Past forestland reallocations may affect households' expectations about reallocation in the future. We expect that a larger frequency of forestland reallocations contributes to lower tenure security.

As Table 2 shows, $75 \%$ of the interviewed households own forest certificates. The frequency of land reallocation is fairly low (only 0.19 ). The mean values of the two actual security variables differ significantly between the group of respondents who expected that land reallocation will not happen, and the group that expected it to happen; this also holds for forestland certificates when the groups are subdivided by land expropriation expectations (see t-test scores in Table 2).

\subsubsection{Household Characteristics}

Household characteristics may significantly influence perceptions of tenure security [49]. In this study, we will examine the impact of the age of the household head, the average education level of the laborers, the share of off-farm employment, the family income, the initial forest area, and the number of forestland plots. In our empirical study, we do not distinguish between family and 
responsibility plots, as in the study sites, most family plots were converted back to collective management. Therefore, the variable "forestland plots" refers to responsibility plots.

The average age of the household heads is 52 years, while the average education level is six years. Education may directly affect households' acceptance of policy information, and thus contribute to a higher level of tenure security perception [50]. On average, $10 \%$ of the household members are engaged in off-farm jobs. Off-farm labor can be seen as an opportunity cost for forest management [7]. The more laborers working off-farm, the higher the possibility that the forest will be left idle. This could lead to a higher perception of losing the land in the future. The mean income ranking score in our sample was 4.14, which indicates that households earn on average 5000-7000 yuan per year. More wealthy households may have a higher social status in the village, and their economic power may bring higher bargaining ability. This makes them more able to protect their forestland, and is expected to contribute positively to their perceived tenure security $[7,50]$. The average initial forestland area is $18 \mathrm{mu}$ for the households in the sample, while the average number of initial forestland plots is less than three. Households with a larger area are more likely to lose land through reallocation (under equalitarian principles) or expropriation in the future. The initial number of plots is a measure of the degree of fragmentation, which is an important proxy of land quality [51]. Land reallocation depends largely on the distribution of plots of different quality over farmers [52]. Hence, the impact of plot number is expected to be negative.

\subsubsection{Village Characteristics}

The village characteristics that we examined include the village-level forest contract period, the distance from village to the township, the village-level per capita income, the education level of the cadres (leaders at village level), and the years that the cadres have been in power. The average contract period is 45.6 years $(=30+0.78 \times(50-30)$ years $)$. The longer the contract period, the more secure the forestland tenure is expected to be. The average distance from the sample villages to the township is $4.8 \mathrm{~km}$. The nearer the village is located to the township, the more likely that forestland will be expropriated due to urban expansion and infrastructure construction. Moreover, forestland that is located closer to the township tends to have a greater value, and villages located closer to townships may have more laborers working off-farm. High forestland value and involvement in off-farm employment can induce reallocations of forestland within a village. The village mean per capita income is 2447 yuan. More economically developed areas are more likely to experience reallocations or expropriation of forestland to facilitate economic development. Therefore, village-level income per capita is expected to have a negative impact on forestland tenure security.

The introduction of the Villager Committee Organization Law in 1988 by the Chinese government allows villagers to elect a village head. However, this policy has not been implemented in all villages. The number of years that the cadres have been in office is used to measure the level of village democracy. The shorter the period that the current village leader has been in office, the more democratic the village is assumed to be [17]. To ensure equal opportunities for all households to hold forestland, more democratic villages are more likely to reallocate the forestland. Higher education levels of the village cadres enable them to better comprehend and carry out the relevant policies. This means that cadres with higher education levels are more likely to follow the central policy to prevent land reallocation. In our study area, the current village cadres have been in charge for 10.8 years, on average. Their average education is 9.8 years, which is 3.1 years longer than the average years of education of the interviewed households.

A regional dummy is introduced to control for unobserved factors that may differ between the two counties in which the villages in our sample are located. Unobserved factors may include historical differences, self-governance differences, and differences in villagers' preferences. 


\subsection{Model Specification}

The basic model is specified as follows:

$$
T_{i}=\alpha+\beta R_{i}+\pi X_{i}+\varepsilon_{i}
$$

where $T_{i}$ represents the forest tenure security perception of household $i$. It takes binary values: 1 for households who think that the forestland will NOT be reallocated or expropriated (secure tenure), and 0 for the other households (insecure tenure). $R_{i}$ indicates the bundle of perceived property rights for household $i$, subdivided into use rights, mortgage rights, and transfer rights. $X_{i}$ is a set of control variables for household $i$, including actual tenure security variables, household characteristics and village characteristics, while $\alpha$ and the vectors $\beta$ and $\pi$ represent the coefficients to be estimated and $\varepsilon_{i}$ is the random disturbance term.

\subsection{Estimation Strategy}

We used probit models to estimate (1). One issue that should be considered in our analysis is the potential endogeneity of property rights awareness. Some unobservable variables (e.g., households' risk preferences) may affect both household awareness of property rights and expectations regarding forestland reallocation or expropriation. To overcome this problem, we adopted a method that is similar to that employed by Mullan et al. [53] and Ma et al. [54]. In their studies of land tenure security and migration, they used village-level averages of tenure security as proxies of household-level tenure security, with the village-level average defined as the average tenure security level of the other sampled households within the same village (not including household $i$ itself). We used a similar method for the property rights variable, and thereby assumed that households living in the same village face similar property rights integrity, and that the tenure security perceptions of one household do not affect the property rights integrity perceptions of other households in the village.

\section{Results and Discussion}

Table 3 presents the regression results for tenure security perceptions related to forestland reallocation (columns (1)-(3)) and expropriation (columns (4)-(6)). The pairwise correlation coefficients of use, mortgage, and transfer rights (which equal 0.15-0.36), and the variance inflation factors (VIF) reported at the bottom of Table 3 (valued around 1.5) indicate that (multi)collinearity is not a major problem.

Columns (1) and (4) present the probit results with household-level property rights variables, while columns (2) and (5) show the results when village-level property rights scores (excluding household $i$ itself) replace the household-level variables. Columns (3) and (6) add the pairwise combinations of use, transfer, and mortgage rights to the equation in order to examine the presence of interaction effects.

\subsection{Property Rights Integrity and Perceived Tenure Security}

The results show that the bundle of forestland rights has different effects on the two types of tenure (in)security perceptions that we examine. When the potential endogeneity of property rights perceptions is taken into account, transfer rights are found to have a significant positive impact (at a $10 \%$ testing level) on expectations that forestland will not be reallocated (see columns (2) and (3) in Table 3). But the estimated coefficients of use rights and mortgage rights do not differ significantly from zero, nor do the interaction terms of the three types of property rights. Furthermore, none of the three property right types is found to have a significant impact on expectations with respect to forestland expropriation. This finding holds when the three property right types are included together, both with and without interaction terms (see columns (4)-(6) in Table 3). 
Table 3. Probit regression results.

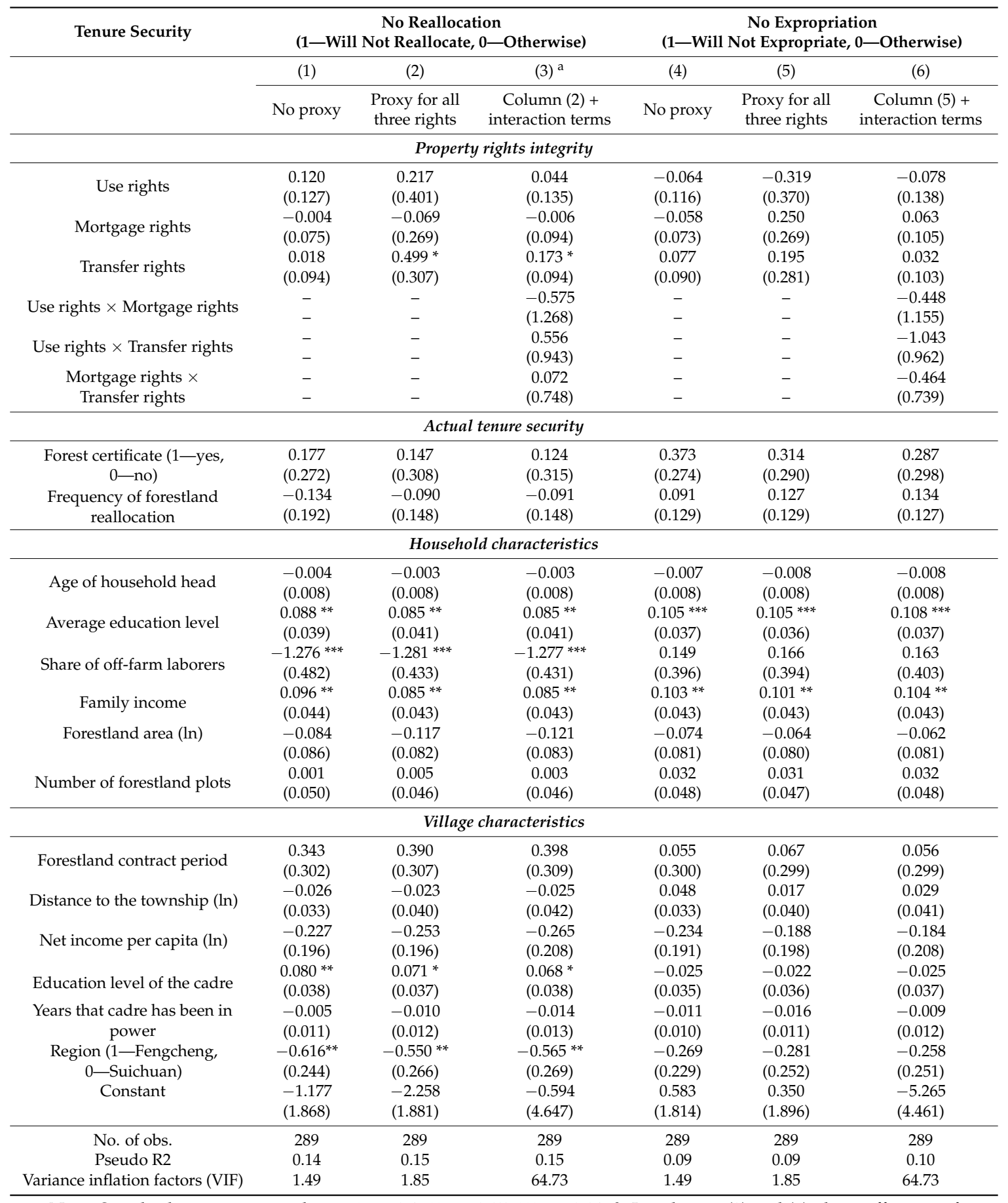

Note: Standard errors in parentheses, ${ }^{*} p<0.1,{ }^{* *} p<0.05,{ }^{* * *} p<0.01{ }^{a}$ : In columns (3) and (6), the coefficients of

use rights, mortgage rights, and transfer rights are marginal values after integrating the interaction terms.

The finding that households' forestland reallocation expectations are affected by transfer rights, while households' perceptions of forestland expropriation are not affected by any of the forestland rights indices, provides evidence supporting Proposition 2. A possible reason why forestland expropriation is not affected by either property rights integrity or actual tenure security variables is that forestland expropriation is conducted for the sake of the 'public interest', and is usually compulsory in China. Consequently, farmers cannot resist land expropriation, particularly in the relatively remote forest areas, whether or not they hold complete property rights or possess forest 
certificates. Therefore, farmers' perceptions of land expropriations are not affected by the status of their land property rights. This echoes the finding of Jacoby et al. [18], who pointed out that expropriation decisions are largely exogenous from the individual farmer's perspective. Land reallocations in rural China are usually decided by village officials and aim to address issues such as demographic changes and unequal land productivity. Land reallocations can either be full-scale or partial. Full-scale reallocation means that all land in the village is redistributed among village households, while partial reallocation means that only the land of those households that experienced demographic changes is reallocated among these households, while the rest of the land remains unaffected [55]. Both full-scale and partial reallocations are decided by the village leaders via a self-governance mode [30].

Regarding the impact of the other property rights integrity variables on forestland reallocation expectations, we find that the estimated coefficients of use rights to forestland do have positive signs in columns (1)-(3) in Table 3, although they are not statistically significant. A possible reason for the insignificant effect of use rights may be that the farmers in our research sites rarely exercised some of the use rights, such as rights to convert forestland into farmland and change forest type, although they are aware that they hold such rights. Therefore, the overall effect of use rights on tenure security perceptions may be weak.

Mortgage rights were also not found to have a significant impact on households' expectations of forestland reallocation. A possible reason is that our research sites are located in a relatively less developed province, where forestland mortgage activities seldom occur and farmers are not aware that they possess mortgage rights. As Table 2 shows, the value of mortgage right awareness is only 1.29 on a scale of $1-3$. Therefore, the village collective usually can decide whether to reallocate the land, regardless of the mortgage rights attached to forestland.

Transfer rights were found to have a positive impact on households' perceived tenure security in columns (2) and (3). This indicates that with the increase of transfer rights, households were more likely to think that forestland would not be reallocated after the expiry of the current contracts. This finding is consistent with the findings of Holden et al. [17] and Yi et al. [7].

\subsection{Control Variables}

The estimation results show that the actual tenure security variables, both the certificate dummy and the frequency of forestland reallocations, do not have a significant effect on perceived tenure security. The reason may be that, despite the widespread efforts to issue land certificates to households in rural Jiangxi, these certificates are often kept in the archives of village committees. Hence, formal contract registration by issuing cultivation contracts to households is often no more than a "paper agreement" $[55,56]$. The issuance of a land certificate, as a result, does not completely eliminate all risks of land reallocation and expropriation, and thereby does little to alleviate farmers' worries about losing land in the future.

The number of years of education of household laborers has a significant positive impact on households' perceptions of tenure security, as expected. The share of off-farm laborers in a household has a negative impact on forestland reallocation perceptions, which also confirms a priori expectations. A higher share of off-farm laborers implies more off-farm income and a higher opportunity cost of engaging in forest management. Hence, their forestland is more likely to be reallocated. Family income has positive effects on households' forestland tenure security. This result is consistent with the findings by Holden and Yohannes [50] and Yi et al. [7], in which income increases households' social status and bargaining ability in the village. Therefore, households with relatively high incomes are more able to protect their forestland in the future, and more likely to perceive high tenure security.

As for village characteristics, as expected, the education of the cadre has a significant positive impact on households' expectations regarding the absence of land reallocations in the future. Finally, the regional dummy variable has a significant negative impact on the forestland reallocation variable, indicating that (controlling for other variables) fewer interviewed households in Suichuan county than in Fengcheng city expected that the forestland would be reallocated. 


\subsection{Discussion}

Insecure property rights have been reported as undermining sound forest management and being a critical driver of deforestation throughout the world [57]. Our conceptual framework (Figure 1) explains how the integrity of property rights to forestland may enhance tenure security and address the challenges facing the adoption of sustainable forest management in China. We argue that the collective forest tenure reform in 2003 has empowered local farmers by providing them with more complete property rights over forestland. Our empirical results provide evidence that such rights, especially the transfer rights, give farmers more control over their resources and enhance their perceived tenure security. The development of land rental markets induced by transfer rights can reduce frequent administrative land reallocations within villages, facilitate the transfer of forestland to higher productive households, and lead to a desirable setting for sustainable forest management.

\section{Conclusions}

Forest tenure reforms aimed at enhancing forestland tenure security by increasing rights' integrity have been implemented in recent years in China and other developing countries (e.g., Vietnam and Ecuador). Against this background, this paper assesses the impacts of households' awareness of their bundles of forestland rights on their tenure security perceptions in China by distinguishing two sources of tenure insecurity: village-level land reallocations based on social security considerations, and state-level land expropriation for the public interest. Household-level and village-level datasets collected in Suichuan county and Fengcheng city in Jiangxi province in 2011 and 2013 have been used to estimate these relationships.

We develop a theoretical framework that explains how the bundle of rights affects tenure security via the growth of land values and the rise of transaction costs for land reallocation and expropriation. We also identify different sources of perceived tenure (in)security by distinguishing between forestland reallocation and expropriation. Insights obtained from our analysis may be relevant for understanding of security of customary tenure systems in other parts of the world. Our empirical findings have lent support to the proposition derived from our framework that households with more complete transfer rights perceive higher forestland tenure security related to (absence of) land reallocations by village officials. However, in contrast to our expectations, household tenure security perceptions related to forestland expropriation are not affected by the bundle of property rights.

The different impacts of property rights on two tenure security variables may be explained by the different decision mechanisms between land reallocation and land expropriation. Forestland expropriation is a compulsory process that is initiated by either the state or the local government for the public interest. The current land laws and regulations, together with their ineffective enforcement, fail to fully protect farmers' forestland rights, and make resistance to forestland expropriation nearly impossible in the face of a strong government. Land reallocation, on the other hand, is conducted by village officials via a self-government mode. An increase of the integrity of forestland rights improves households' ability to contest land reallocation. Therefore, we conclude that different types of property rights have different effects on two main sources of forestland tenure (in)security in rural China.

Some policy implications can be derived from our findings. To increase households' forestland tenure security perceptions, and thereby promote sustainable development of forest resources, we suggest to identify the main source of local tenure insecurity. If tenure insecurity mainly arises from arbitrary land expropriations which farmers can hardly resist, policymakers may consider clarifying relevant laws and regulations in more detail, e.g., by defining the scope of "public interest" more precisely and making appropriate compensation provisions. If land reallocation is the major cause of tenure insecurity, more complete transfer rights to forestland may be granted to farmers and policies may be adopted to promote farmers' awareness of such transfer rights. As our empirical results indicate, these rights are expected to strengthen tenure security related to (absence of) land reallocations. Secondly, our results show that household awareness of forestland mortgage rights is 
low. Thus, it is important for the government to increase farmers' awareness of their rights to use forestland as collateral in obtaining loans and stimulate forestland mortgage markets.

Author Contributions: Y.Z., X.M., and D.J. conceived and designed the surveys held in Jiangxi Province; X.M., D.J., X.S., and H.L. collected the data and other materials; Y.Z., X.M., and N.H. analyzed the data; Y.Z., D.J., and N.H. wrote the paper.

Acknowledgments: Financial support for this paper has been gratefully received from the National Key R\&D Program of China (the SURE+ Project, 2016YFE0103100), the National 111 Project (B17024), the National Natural Science Foundation of China (71373127, 71573134, 71603121 and 71503174), and the China Postdoctoral Science Foundation (2016M601839).

Conflicts of Interest: The authors declare no conflict of interest.

\section{References}

1. Chen, J.; Innes, J.L. The implications of new forest tenure reforms and forestry property markets for sustainable forest management and forest certification in China. J. Environ. Manag. 2013, 129, $206-215$. [CrossRef] [PubMed]

2. Deininger, K.; Ali, D.A.; Alemu, T. Impacts of Land Certification on Tenure Security, Investment, and Land Market Participation: Evidence from Ethiopia. Land Econ. 2011, 87, 312-334. [CrossRef]

3. Ma, X.; Heerink, N.; Ierland, E.V.; Berg, M.V.D.; Shi, X. Land Tenure Security and Land Investments in Northwest China. China Agric. Econ. Rev. 2013, 5, 281-307. [CrossRef]

4. Place, F.; Otsuka, K. Land Tenure Systems and Their Impacts on Agricultural Investments and Productivity in Uganda. J. Dev. Stud. 2002, 38, 105-128. [CrossRef]

5. Qin, P.; Xu, J. Forest land rights, tenure types, and farmers' investment incentives in China: An empirical study of Fujian Province. China Agric. Econ. Rev. 2013, 5, 154-170. [CrossRef]

6. Xie, Y.; Wen, Y.; Zhang, Y.; Li, X. Impact of property rights reform on household forest management investment: An empirical study of southern China. For. Policy Econ. 2013, 34, 73-78. [CrossRef]

7. Yi, Y.; Köhlin, G.; Xu, J. Property Rights, Tenure Security and Forest Investment Incentives: Evidence from China's Collective Forest Tenure Reform. Environ. Dev. Econ. 2014, 19, 48-73. [CrossRef]

8. Li, J.; Bluemling, B.; Dries, L. Property Rights Effects on Farmers' Management Investment in Forestry Projects: The Case of Camellia in Jiangxi, China. Small-Scale For. 2016, 15, 271-289. [CrossRef]

9. Dinh, H.H.; Nguyen, T.T.; Hoang, V.N.; Wilson, C.; Dinh, H.H.; Nguyen, T.T.; Hoang, V.N.; Wilson, C. Economic incentive and factors affecting tree planting of rural households: Evidence from a Central Highlands province of Vietnam. J. For. Econ. 2017, 29, 14-24. [CrossRef]

10. Xu, X.; Zhang, Y.; Li, L.; Yang, S. Markets for Forestland Use Rights: A Case Study in Southern China. Land Use Policy 2013, 30, 560-569. [CrossRef]

11. Zhu, X.; Zhang, H.; He, W. Forest Tenure Reform, Forest Tenure Structure and Households' Decision-making of Forest Land Transferring. Res. Inst. Econ. 2014, 4, 170-187. (in Chinese).

12. Liu, C.; Lu, J.; Yin, R. An Estimation of the Effects of China's Priority Forestry Programs on Farmers' Income. Environ. Manag. 2010, 45, 526-540. [CrossRef] [PubMed]

13. Liu, C.; Mullan, K.; Liu, H.; Zhu, W.; Rong, Q. The estimation of long term impacts of China's key priority forestry programs on rural household incomes. J. For. Econ. 2014, 20, 267-285. [CrossRef]

14. Liu, T.; Liu, C.; Liu, H.; Wang, S.; Rong, Q.; Zhu, W. Did the Key Priority Forestry Programs Affect Income Inequality in Rural China? Land Use Policy 2014, 38, 264-275. [CrossRef]

15. Xie, L.; Berck, P.; Xu, J. The effect on forestation of the collective forest tenure reform in China. China Econ. Rev. 2016, 38, 116-129. [CrossRef]

16. Holland, M.B.; Jones, K.W.; Naughton-Treves, L.; Freire, J.L.; Morales, M.; Suárez, L. Titling land to conserve forests: The case of Cuyabeno Reserve in Ecuador. Glob. Environ. Chang. 2017, 44, 27-38. [CrossRef]

17. Holden, S.; Xu, J.; Jiang, X. Collective versus Individual Property: Tenure Security and Forest Tenure Reforms in China. In Centre for Land Tenure Studies Working Paper; Norwegian University of Life Sciences (UMB): Ås, Norway, 2011; p. 28.

18. Jacoby, H.G.; Li, G.; Rozelle, S. Hazards of Expropriation: Tenure Insecurity and Investment in Rural China. Am. Econ. Rev. 2002, 92, 1420-1447. [CrossRef] 
19. Xu, X.; Zheng, X. On the Problems and Reform of the System of Taking over Forestland for Use in China. For. Resour. Manag. 2005, 1, 18-21. (In Chinese).

20. State Forestry Administration of China. An Inspection of Forest Occupation and Expropriation in 2011. Available online: http:/ / www.forestry.gov.cn/portal/main/s/195/content-532983.html (accessed on 1 June 2018).

21. State Forestry Administration of China. An Inspection of Forest Occupation and Expropriation in 2012. Available online: http:/ / www.chinatimber.org/news/show.asp?id=49304 (accessed on 1 June 2018).

22. FAO. Reforming Forest Tenure: Issues, Principles and Process. Available online: http://www.fao.org/ docrep/014/i2185e/i2185e00.pdf (accessed on 1 June 2018).

23. FAO. Land Tenure and Rural Development Projects. Available online: http://www.fao.org/DOCREP/005/ Y4307E/y4307e00.htm (accessed on 1 June 2018).

24. Ye, J.; $\mathrm{Xu}, \mathrm{Q}$. The measurement and improvement of the rural land property right structure of China: Based on the analysis of the seventeen-province rural land sample surveys in 2001 and 2005. J. Huazhong Norm. Univ. (Humanit. Soc. Sci.) 2007, 46, 48-53. (In Chinese).

25. Dai, G.; Xu, J.; Wang, Y. Study on Chinese collective forest property status and security. Green Chin. 2002, 11, 30-33. (In Chinese).

26. Wu, J. The research of Chinese land tenure security: The connotation and measurement. Chin. Rural Surv. 2009, 2, 19-24. (In Chinese).

27. Sjaastad, E.; Bromley, D.W. The Prejudices of Property Rights: On Individualism, Specificity, and Security in Property Regimes. Dev. Policy Rev. 2000, 18, 365-389. [CrossRef]

28. Arnot, C.D. What Is Tenure Security? Conceptual Implications for Empirical Analysis. Land Econ. 2011, 87, 297-331. [CrossRef]

29. Van Gelder, J.L. What tenure security? The case for a tripartite view. Land Use Policy 2010, 27, 449-456. [CrossRef]

30. Ma, X.; Heerink, N.; Feng, S.; Shi, X. Farmland tenure in China: Comparing legal, actual and perceived security. Land Use Policy 2015, 42, 293-306. [CrossRef]

31. Holden, S.T.; Otsuka, K.; Deininger, K. Land Tenure Reforms, Poverty and Natural Resource Management: Conceptual Framework. In Land Tenure Reform in Asia and Africa: Assessing Impacts on Poverty and Natural Resource Management; Palgrave Macmillan: London, UK, 2013.

32. Besley, T. Property Rights and Investment Incentives: Theory and Evidence from Ghana. J. Political Econ. 1995, 103, 903-937. [CrossRef]

33. Deininger, K.; Jin, S. Tenure Security and Land-related Investment: Evidence from Ethiopia. Eur. Econ. Rev. 2006, 50, 1245-1277. [CrossRef]

34. Deininger, K.; Jin, S. Land Rental Markets as an Alternative to Government Reallocation? Equity and Efficiency Considerations in the Chinese Land Tenure System. In SSRN Working Paper Series; World Bank Policy Research Working Paper 2930; World Bank: Washington, DC, USA, 2005.

35. Tao, R.; Xu, Z. Urbanization, rural land system and social security for migrants in China. J. Dev. Stud. 2007, 43, 1301-1320. [CrossRef]

36. Yang, Y.F. Basic Land Security and Livelihood: A Study of Compensation and Social Security Policy for Land-Expropriated Peasants in China. Public Adm. Dev. 2012, 32, 385-401. [CrossRef]

37. Pils, E. Assessing evictions and expropriations in China: Efficiency, credibility and rights. Land Use Policy 2016, 58, 437-444. [CrossRef]

38. Hui, E.C.M.; Bao, H.J.; Zhang, X.L. The policy and praxis of compensation for land expropriations in China: An appraisal from the perspective of social exclusion. Land Use Policy 2013, 32, 309-316. [CrossRef]

39. Feng, L.; Bao, H.X.H.; Jiang, Y. Land Reallocation Reform in Rural China: A Behavioral Economics Perspective. Land Use Policy 2014, 41, 246-259. [CrossRef]

40. Lin, J.Y. The Household Responsibility System in China's Agricultural Reform: A Theoretical and Empirical Study. Econ. Dev. Cult. Chang. 1988, 36, S199-S224. [CrossRef]

41. Xie, Y.; Gong, P.; Han, X.; Wen, Y. The effect of collective forestland tenure reform in China: Does land parcelization reduce forest management intensity? J. For. Econ. 2014, 20, 126-140. [CrossRef]

42. Delang, C.O.; Wang, W. Chinese Forest Policies in the Age of Decentralisation (1978-1997). Int. For. Rev. 2013, 14, 13-26. [CrossRef] 
43. Xu, J.; Jiang, X. Collective forest tenure reform in China: Outcomes and implications. In Proceedings of the World Bank Conference on Land Governance 2009, Washington, DC, USA, 9-10 March 2009. Available online: http:/ / www.sifi.se/wp-content/uploads/2013/02/Xu-Jintao.pdf (accessed on 1 May 2018).

44. Zheng, F.; Ruan, R.; Kong, X. Review and analysis of forest property right system reform in the south. Chin. Popul. Resour. Environ. 2009, 19, 25-32.

45. Liu, D.; Edmunds, D. Devolution as a Means of Expanding Local Forest Management in South China: Lessons from the Past 20 Years. In China's Forests. Global Lessons from Market Reforms; Hyde, W.F., Belcher, B., Xu, J., Eds.; Resources for the Future Press: Washington, DC, USA, 2003.

46. Yin, R.; Xu, J. A Welfare Measurement of China's Rural Forestry Reform during the 1980s. World Dev. 2002, 30, 1755-1767. [CrossRef]

47. Yin, R.; Yao, S.; Huo, X. China's forest tenure reform and institutional change in the new century: What has been implemented and what remains to be pursued? Land Use Policy 2013, 30, 825-833. [CrossRef]

48. State Forestry Administration of China. China Forestry Statistical Yearbook 2014. Available online: http: / / data.forestry.gov.cn/lysjk/indexJump.do?url=view / moudle/searchData/showDetail\&keyid=1004576 (accessed on 1 June 2018).

49. Deng, Z.; Zhang, J.; Xu, Z. Study on households' cognition and behavior in the improvement of rural environment. Agric. Technol. Econ. 2013, 2, 72-79. (in Chinese).

50. Holden, S.; Yohannes, H. Land Redistribution, Tenure Insecurity, and Intensity of Production: A Study of Farm Households in Southern Ethiopia. Land Econ. 2002, 78, 573-590. [CrossRef]

51. Tan, S.; Heerink, N.; Qu, F. Land fragmentation and its driving forces in China. Land Use Policy 2006, 23, 272-285. [CrossRef]

52. Rao, F.; Spoor, M.; Ma, X.; Shi, X. Perceived land tenure security in rural Xinjiang, China: The role of official land documents and trust. China Econ. Rev. 2017. [CrossRef]

53. Mullan, K.; Grosjean, P.; Kontoleon, A. Land Tenure Arrangements and Rural-Urban Migration in China. World Dev. 2011, 39, 123-133. [CrossRef]

54. Ma, X.; Heerink, N.; Ierland, E.V.; Shi, X. Land tenure insecurity and rural-urban migration in rural China. Pap. Reg. Sci. 2016, 95, 383-406. [CrossRef]

55. Rao, F.; Spoor, M.; Ma, X.; Shi, X. Land tenure (in)security and crop-tree intercropping in rural Xinjiang, China. Land Use Policy 2016, 50, 102-114. [CrossRef]

56. Ho, P.; Spoor, M. Whose Land? The Political Economy of Land Titling in Transitional Economies. Land Use Policy 2006, 23, 580-587. [CrossRef]

57. White, A.; Martin, A. Who owns the world's forests? Forest Tenure and Public Forests in Transition. In Forest Trends; Center for International Environmental Law: Washington, DC, USA, 2002; p. 30. 